\title{
Gripe espanhola: fluxos encadeados de memória e lapidação das lembranças
}

\author{
Spanish flu: interconnected streams of memory and polishing \\ reminiscences
}

Gripe española: corrientes de memoria encadenadas y tallando recuerdos

\author{
Marialva Carlos Barbosa ${ }^{1, a}$ \\ marialva153@gmail.com | https://orcid.org/0000-0001-8875-7128 \\ ${ }^{1}$ Universidade Federal do Rio de Janeiro, Escola de Comunicação, Programa de Pós-Graduação em Comunicação e
Cultura. Rio de Janeiro, RJ, Brasil. \\ a Doutorado em História pela Universidade Federal Fluminense.
}

\section{RESUMO}

Por meio da autoetnografia, na qual a experiência do pesquisador se inter-relaciona com o cenário empírico que analisa, o artigo desenvolve como se articulam, em atos comunicacionais, os fluxos encadeados de memória, haja vista um evento traumático contemporâneo. A pandemia da Covid-19 faz emergir lembranças de um passado que sobreviveu pelas narrativas de outro, a gripe espanhola de 1918, nas memórias de infância de quem hoje faz o gesto de contar essa história. Apresentam-se, ainda, aspectos da cobertura jornalística realizada na época pelos principais periódicos do Rio de Janeiro que também produzem narrativas governadas pela lógica dos fluxos encadeados de memória.

Palavras-chave: Gripe espanhola; Autoetnografia; Memória; Periódicos; Rio de Janeiro.

\section{ABSTRACT}

Through the autoethnography, in which the researcher's experience is interrelated with the empirical scenario that she or he analyzes, the article reveals how the interconnected streams of memory are articulated in communicational acts, taking into account a contemporary traumatic event. The Covid-19 pandemic gives rise to reminiscences of a past that survived because of the narratives of another event, 
the 1918 influenza pandemic (Spanish flu), in the childhood memories of the one who nowadays makes the gesture of telling that story. Moreover, the article presents aspects of journalistic coverage then carried out in Rio de Janeiro by the main newspapers and magazines, which also produce narratives guided by the interconnected streams of memory logic.

Keywords: Spanish flu; Autoethnography; Memory; Newspapers and magazines; Rio de Janeiro.

\section{RESUMEN}

Por medio de la autoetnografía, en que la experiencia del investigador está interrelacionada con el escenario empírico que analiza, el artículo desarrolla cómo se articulan las corrientes encadenadas de la memoria en actos comunicacionales, teniendo en cuenta un evento traumático contemporáneo. La pandemia de coronavirus desencadena recuerdos de un pasado que sobrevivió debido a las narraciones de otro evento, la gripe española de 1918, en las memorias de la infancia de quien hoy en día hace el gesto de narrar esa historia. Además, el artículo presenta aspectos de la cobertura periodística llevada a cabo en la época por los principales periódicos y revistas de Río de Janeiro que también producen narrativas regidas por la lógica de las corrientes encadenadas de memoria.

Palabras clave: Gripe española; Autoetnografía; Memoria; Periódicos y revistas; Rio de Janeiro.

Este artigo compõe o Dossiê Comunicação, Saúde e Crises Globais.

Contribuição dos autores:

Concepção e desenho do estudo: Marialva Carlos Barbosa.

Aquisição, análise ou interpretação dos dados: Marialva Carlos Barbosa.

Redação do manuscrito: Marialva Carlos Barbosa.

Revisão crítica do conteúdo intelectual: Marialva Carlos Barbosa.

Declaração de conflito de interesses: não há.

Fontes de financiamento: não houve.

Considerações éticas: não há.

Agradecimentos/Contribuições adicionais: Agradeço a Raquel Paiva a sugestão da utilização da autoetnografia para a construção deste artigo.

Histórico do artigo: submetido: 14 maio 2020 | aceito: 5 jun. 2020 | publicado: 17 dez. 2020.

Apresentação anterior: não há.

Licença CC BY-NC atribuição não comercial. Com essa licença é permitido acessar, baixar (download), copiar, imprimir, compartilhar, reutilizar e distribuir os artigos, desde que para uso não comercial e com a citação da fonte, conferindo os devidos créditos de autoria e menção à Reciis. Nesses casos, nenhuma permissão é necessária por parte dos autores ou dos editores. 


\section{INTRODUÇÃO}

A proposta do artigo é refletir, por meio da autoetnografia, sobre o que estamos denominando fluxos encadeados de memória, colocando em relação lembranças localizadas no longínquo ano de 1918 referentes à gripe espanhola e as vivências do tempo presente, governado pela experiência traumática diante de uma nova pandemia, a Covid-19.

A realização do que metodologicamente é definido como autoetnografia ${ }^{1-3}$ coloca em destaque a experiência do eu autor, que aciona imagens-lembranças do passado no presente, considerando como pressuposto que a memória é sempre do presente 4 . Dessa forma, mediante o ato narrativo, o eu autor vai reconstruindo, narrando e interpretando as suas experiências. Não se trata de uma autobiografia, ainda que na autoetnografia esteja sempre presente a biografia pessoal do pesquisador, já que envolve sua inserção num espaço social de relações - objeto a ser compreendido e interpretado - por intermédio de seus trabalhos memoráveis. Assim, embora tenha aspecto autonarrativo predominante, funciona como porta de entrada para a compreensão de um cenário analítico e interpretativo mais amplo, no qual se constrói, em novas bases, a relação entre o sujeito que observa e o mundo que é observado. Embora o foco narrativo esteja concentrado na palavra do pesquisador, suas histórias, seus pensamentos e seus sentimentos, tudo isso relaciona-se a um mundo social, no qual outras questões estão envolvidas, ainda que sua experiência seja determinante na produção do conhecimento.

Outro aspecto que devemos ressaltar diz respeito à experiência temporal num texto memorial que se refere a um passado longínquo. A reapropriação e a reencenação desse passado no presente são dependentes das peculiaridades do tempo atual, que aciona, pela experiência vivida hoje, pedaços e recortes significativos de lembrança. Portanto, num fluxo em que presente/passado é construído haja vista uma experiência traumática, no caso do artigo, a memória, até então apaziguada sobre esse passado, torna-se memória disruptiva. De todo modo, há a recomposição das lembranças necessárias para dar coerência aos percursos trilhados pelo próprio autor. Serão essas trilhas, espécies de labirintos da memória, que serão descritas num texto que pode ser construído, como é o caso aqui, em primeira pessoa. Envolve, sempre, um trabalho de introspecção, uma recordação emocional para compreender as experiências vividas, interpretando a própria experiência como história. Trata-se de escrever uma história a partir de si mesmo, em que se reconhece e se inclui como fundamental a experiência do pesquisador, numa memória labiríntica que une numa temporalidade cambiante presente/passado e passado/presente.

São, enfim, narrativas pessoais que destacam aspectos de uma vida que se cruza com o contexto cultural, produzindo uma conexão com outros que partilharam experiências semelhantes. Há, implicitamente, um convite ao leitor para entrar no mundo do autor, fazendo também o movimento de refletir sobre suas próprias vidas, compreendê-las e de lidar com elas ${ }^{1}$.

\section{LAPIDAÇÃO DE LEMBRANÇAS}

Quando eu era bem pequena, escutava sempre meu pai contar uma história que, aos meus ouvidos, parecia estranha e improvável. Uma cena de caminhões repletos de cadáveres que recolhiam pelas ruas muitos corpos, colocando uns em cima dos outros. A esse espetáculo macabro, ele ainda acrescentava outra descrição: valas abertas nas quais se despejavam mais corpos, tal a quantidade de gente que morria pela cidade, sobretudo nos subúrbios.

Dizia para mim que eu deveria ter, naquele momento, talvez a mesma idade que ele tinha quando presenciara aquelas cenas que ficaram guardadas nas suas lembranças sobre a gripe espanhola de 1918. Ele, que nascera em março de 1910, tinha naquele outubro pouco mais de 8 anos. As imagens ficaram permanentemente martelando na sua cabeça e volta e meia a elas se referia. Eu escutava e não entendia 
bem. Aliás, jamais entendi (e as tinha esquecido completamente) até chegar aos anos 20 do século XXI e enfrentar uma doença que guarda inúmeras aproximações com a influenza anunciada como a primeira pandemia do século XX, a gripe espanhola.

A vivência cotidiana numa época inundada de informações, o que provoca muitas vezes irremediáveis desinformações, com uma doença desconhecida e que também é decorrente de um vírus fez novamente as descrições de meu pai voltarem vivas às minhas lembranças. Com elas, voltou um tempo em que a gente do subúrbio não tinha médicos, em que se cobriam os vidros das janelas com papel vermelho, como medida curativa. Dizia-se então que era contra o sarampo (mas que funcionava como sinal expresso de que ali havia um enfermo de uma doença contagiosa). Um tempo em que na casa vizinha existia irremediavelmente um tuberculoso, doença sem cura e que, diante da insalubridade das habitações e da alimentação deficiente, ceifava vidas sem piedade. Não havia vacinas, não havia médicos, pelo menos para os pobres.

Quando determinada enfermidade tomava conta de algum de nós, o caminho certeiro era a rezadeira, única esperança de cura. Uma mulher, sempre enigmática aos olhos de uma criança, morando habitualmente em uma casa pequena, na qual entrávamos em cubículos mal iluminados, cercados de velas, ervas frescas e secas, inúmeras imagens de santos e fitas em altares que tomavam conta de todos os ambientes. Ela rezava tudo: mau-olhado, quebranto, espinhela caída, barriga-d’água, males diversos de nomes estranhos. As crianças do início do século XX tinham excesso de mau-olhado: poliomielite, sarampo, catapora, coqueluche, varíola, caxumba. Tudo era mau-olhado.

As imagens desse tempo de muitas doenças produzem irremediavelmente as lembranças das muitas crianças com uma perna menor ou mais fina do que a outra, sobreviventes que eram da paralisia infantil; dos adultos com o pescoço tomado por uma enorme papada, que depois descobriu chamar-se bócio; de velhos alquebrados pelas ruas carregando nas pernas inúmeras feridas decorrentes da erisipela. Morria-se de tudo. Era possível, tal qual meu avô, tomar um banho depois de comer e morrer de repente; podia-se deitar e amanhecer morto; podiam-se ver o ventre inchando e a morte sorrateira chegando. Morria-se de tudo e de nada, já que jamais sabíamos os nomes daquelas doenças. Ninguém sabia.

Nos subúrbios podia muito raramente aparecer algum médico, poucos, mas, por vezes, havia. Abnegados profissionais que cuidavam de todos e de tudo. Num tempo sem especialidade médica, era o médico - às vezes um único para uma extensa região - das crianças, dos adultos, dos velhos. Os consultórios modestos sempre lotados, o sorriso sempre pronto, a escuta paciente também. Médicos de pobres, pobres desamparados dos subúrbios do Rio de Janeiro.

Nesse ambiente de muitas doenças e muitas curas - graças aos preceitos da rezadeira e dos escassos médicos abnegados que ali atendiam -, escutava as histórias contadas por meu pai. Uma delas foi especialmente importante para mim. Vez por outra, sentado numa cadeira na varanda improvisada da nossa casa, ele descrevia cenas da gripe espanhola de 1918. Duas, particularmente, faziam parte da sua narrativa.

Na primeira delas, como já anunciei brevemente, sempre descrevia a cena de caminhões repletos de corpos, passando em frente à sua casa no Engenho de Dentro, bairro da zona suburbana da cidade do Rio de Janeiro, servido pelo ramal ferroviário da Central do Brasil. Na sua minuciosa narrativa, o caminhão seguia pelas ruas recolhendo corpos que estavam depositados nas casas, nas calçadas ou mesmo caídos junto aos meios-fios. Era tanta a quantidade de corpos que era preciso colocar uns sobre os outros, alguns enrolados em velhos trapos do que um dia fora um lençol, mas a maioria era depositada tal como havia sido encontrada, alguns já em estado de putrefação. Ele nunca falava dos cheiros, mas a minha imaginação completava os possíveis odores que saíam desses carros que transportavam dezenas de mortos.

A segunda cena que se materializava mediante suas lembranças duradouras, que caminhavam na minha direção, impregnando minha memória por meio das suas narrativas, se referia às valas que eram abertas para que, ali, corpos fossem depositados. Era tanta a quantidade de mortos que passaram a enterrar 
coletivamente os cadáveres em valas abertas ao longo das vias públicas. Os corpos empilhavam-se pelo chão, e para resolver a situação era preciso, segundo meu pai, providenciar ali mesmo o sepultamento improvisado de milhares de vítimas da gripe espanhola.

Quase 60 anos depois, quando o mundo e o Brasil foram impactados pela pandemia da Covid-19, de maneira contundente essas narrativas foram acionadas nas minhas lembranças e tão presentes ficaram que chego mesmo a escutar a entonação da voz de meu pai falando. Minuciosamente, ele relatava cada detalhe. $\mathrm{Eu}$, na época, olhava espantada sem saber ao certo do que ele falava.

Nunca soube. Só vim a sabê-lo décadas depois, quando em quarentena e diante das informações que pelas infovias digitais passam a percorrer o mundo e a dar a dimensão da tragédia da primeira pandemia do século XXI. Lentamente, fui compreendendo o vigor daquelas narrativas e o impacto que provocaram num menino de 8 anos e que, ao serem recontadas, também o causaram numa menina de 8 anos.

Imagens duradouras, fixadas de maneira permanente nas lembranças de meu pai, de tal forma que era preciso delas falar para o outro, que se transformava em testemunha indireta daqueles acontecimentos monstruosos. Fazia-se necessário multiplicar os testemunhos para que aqueles horrores não fossem jamais esquecidos. E não o foram.

Percebi, então, que os trabalhos de memória de meu pai sobreviveram nas minhas lembranças, permitindo que eu acionasse novamente aquelas imagens que ficaram guardadas nas suas retinas e que foram transmitidas a mim pelo fluxo das narrativas. Elas permaneceram adormecidas como lembranças apaziguadas, para voltarem no momento em que imagens semelhantes as acionaram. Dessa forma, as lembranças do menino de 8 anos sobrevivem nas da menina da mesma idade, que as deixara adormecidas por um longo período. No instante propício, as mesmas cenas voltaram com tal intensidade que aquilo que fora presenciado por meu pai ganhou vida outra vez. As lembranças duradouras do momento traumático de sua infância, como num fluxo, foram transmitidas a seus descendentes, que, num movimento também de fluxo, buscam agora as cenas primordiais daquele acontecimento. Se as cenas, de fato, existissem, estaria atestada uma espécie de veracidade narrativa das histórias memoráveis de meu pai e, de certa maneira, a verdade também da minha própria memória.

\section{EM BUSCA DA MEMÓRIA PERDIDA}

Pelo meu olhar de historiadora, fiz, então, o gesto de buscar essas imagens veritativas da memória e mergulhei em dezenas de páginas de periódicos publicados de setembro a novembro de 1918, na esperança de encontrar fotografias que, para mim, se transformaram em sínteses da gripe espanhola de 1918: o caminhão com cadáveres e as valas abertas nas ruas dos subúrbios.

Nos principais jornais da época - Correio da Manhã, O Paiz, Gazeta de Notícias e A Noite ${ }^{\mathrm{i}}$ - descobri muitas descrições e poucas imagens, já que os diários ainda não publicavam ilustrações com a intensidade que o fariam posteriormente, mas as narrativas acerca da tragédia que se abatia sobre a cidade e que se intensificou a partir de 20 de outubro de 1918 causaram muitas impressõesii

A primeira e a mais importante foi a descoberta de semelhanças assustadoras entre os principais acontecimentos em torno daquela gripe e o que estamos vivendo hoje: a crise na então Diretoria-Geral

i Até o fim da década de 1920, o Correio da Manhã, fundado em 1901, O Paiz, que começou a circular em 1884, e Gazeta de Notícias, criado em 1875, estavam entre os matutinos de maior circulação no país. Já A Noite, fundado em 1911, era o vespertino de maior tiragem da cidade ${ }^{5}$.

ii O Correio da Manhã foi investigado de 28 de setembro a 11 de novembro de 1918. O Paiz, de 23 de setembro a 10 de novembro de 1918. A Gazeta de Notícias, de 12 de outubro a 10 de novembro de 1918. Por fim, A Noite, de 25 d setembro a 4 de novembro de 1918 
de Saúde Públicaiii, que levou à demissão do seu diretor no momento mais drástico da epidemia; as recomendações médicas, que incluíam o que hoje chamamos de distanciamento social; o aparecimento de drogas milagrosas, anunciadas aos quatro ventos nas páginas das publicações; as ruas vazias, em decorrência da quantidade de doentes; o colapso dos hospitais, com leitos tomados e muitos enfermos sem nenhuma assistência; os incontáveis enterros nos cemitérios da cidade, obrigando a utilização de prisioneiros da Casa de Detenção como coveiros; a multidão de pobres nos subúrbios que ia aos postos improvisados da assistência em busca de pão, água e sopa, indispensáveis para matar a fome dos muitos que a sentiam; e as imagens dos morros da cidade, cujos moradores ficaram sem assistência, entregues à própria sorte.

É como se o tempo não tivesse passado e as mesmas personagens voltassem das trevas para nos assombrar por terem morrido pela pobreza, pela desigualdade social, pela falta de condições de vida digna, pela fome que sentiam.

As descrições nos periódicos, diversas vezes, narram os acontecimentos memoráveis de meu pai. Algumas, pela contundência e pela minúcia dos detalhes ao descrever os corpos nos caminhões apinhados, são particularmente impactantes. Transcrevo um dos trechos: "Os carroções automóveis andaram em todas as ruas, repletos de mortos amontoados, uns por cima dos outros, de todas as cores, a desprenderem horrível fétido, sem que tivessem a miséria de uma simples coberta de lona, para esconder o triste destino que lhes foi reservado'. Em grande número de ruas continuaram a ser depositados cadáveres, em plena decomposição, e ficavam horas a fio nas calçadas, sob a soalheira forte do dia de ontem, que mais aumentava a podridão da carne humana! Isso dura há oito dias e todo um governo, a fingir mil e uma providências, não teve como fazer cessar essa monstruosidade. Decididamente, ou somos um povo de irracionais, ou os administradores perversos e cretinos que nos desgovernam, há de receber castigo implacável. Nem Deus terá coragem para os salvar”6 (p. 1, grifo nosso).

Na busca incansável de imagens, no momento seguinte, fui na direção das revistas críticas e de costume de grande tiragem: Careta, O Malho e Revista da Semanaiv. E lá estavam elas. Dezenas tentando captar o espírito do tempo e imortalizar para o futuro cenas de uma doença que mudara completamente a fisionomia da cidade ${ }^{\mathrm{v}, 7}$.

As imagens queriam mostrar um momento qualificado como "a tenebrosa situação da Capital da República"8 (p. 8), na qual "um povo tragicamente era flagelado por uma calamidade instantânea, fulminante e contínua"8 (p. 8). Na linguagem hiperbólica própria dos periódicos do início do século $\mathrm{XX}$, descreviam-se "os muitos horrores de uma doença perigosamente contagiosa"8 (p. 8), que estendera "os seus malefícios por toda a vastidão da cidade, prostrando no leito a metade da população" ${ }^{8}$ (p. 8).

As primeiras fotos que acompanhavam o texto mostravam lado a lado imagens de dois doentes na Praça XV de Novembro, no centro da cidade. Ambos estão sentados à beira de um canteiro. Um com os braços cruzados olha para o chão, enquanto o segundo encontra forças para levantar a cabeça e fixar a câmera. Na mesma edição são publicadas mais nove fotos. Na última (Figura 1), publicada na página 21, lá está ela: a cena memorável fixada permanentemente nas retinas de meu pai.

iii A Diretoria-Geral de Saúde Pública, responsável pelo combate à epidemia, foi alvo de intensa campanha dos principais jornais da cidade, que acusaram seu diretor na época, Carlos Seidl, de ser o grande responsável pelo avanço da doença (classificada por ele, quando de sua eclosão, como benigna) e por milhares de mortes que ocasionou, bem como pela completa desorganização sanitária e hospitalar da cidade. Alguns jornais, como a Gazeta de Notícias, chamavam a gripe espanhola de "mal de Seidl" e, por semanas, fizeram intensa campanha contra o diretor do órgão, que foi afastado das suas funções nas últimas semanas de outubro de 1918, quando a cidade vivia o momento mais grave da epidemia ${ }^{7}$.

iv As mais importantes revistas ilustradas que circulavam na cidade nas duas primeiras décadas do século XX eram: Careta, criada em 1908, O Malho, de 1902, e Revista da Semana, publicação semanal do Jornal do Brasil, que começou a circular em 1901. Pelas suas características editoriais, em que se destaca a crítica jocosa aos costumes, preferimos qualificá-las como revistas críticas e de costumes ${ }^{5}$.

v Foram publicadas mais de 40 fotografias em cinco edições da revista Careta entre outubro e novembro de 1918: edições 540 , de 26 de outubro de 1918; 541, de 2 de novembro de 1918; 542, de 9 de novembro de 1918; 543, de 16 de novembro de 1918; e 544, de 23 novembro de 1918. O conteúdo dessas edições e outros periódicos da época encontra-se disponível no site da Biblioteca Nacional, em Hemeroteca Digital: http://bndigital.bn.gov.br/hemeroteca-digital/. Acesso em: 09 abril 2020. 


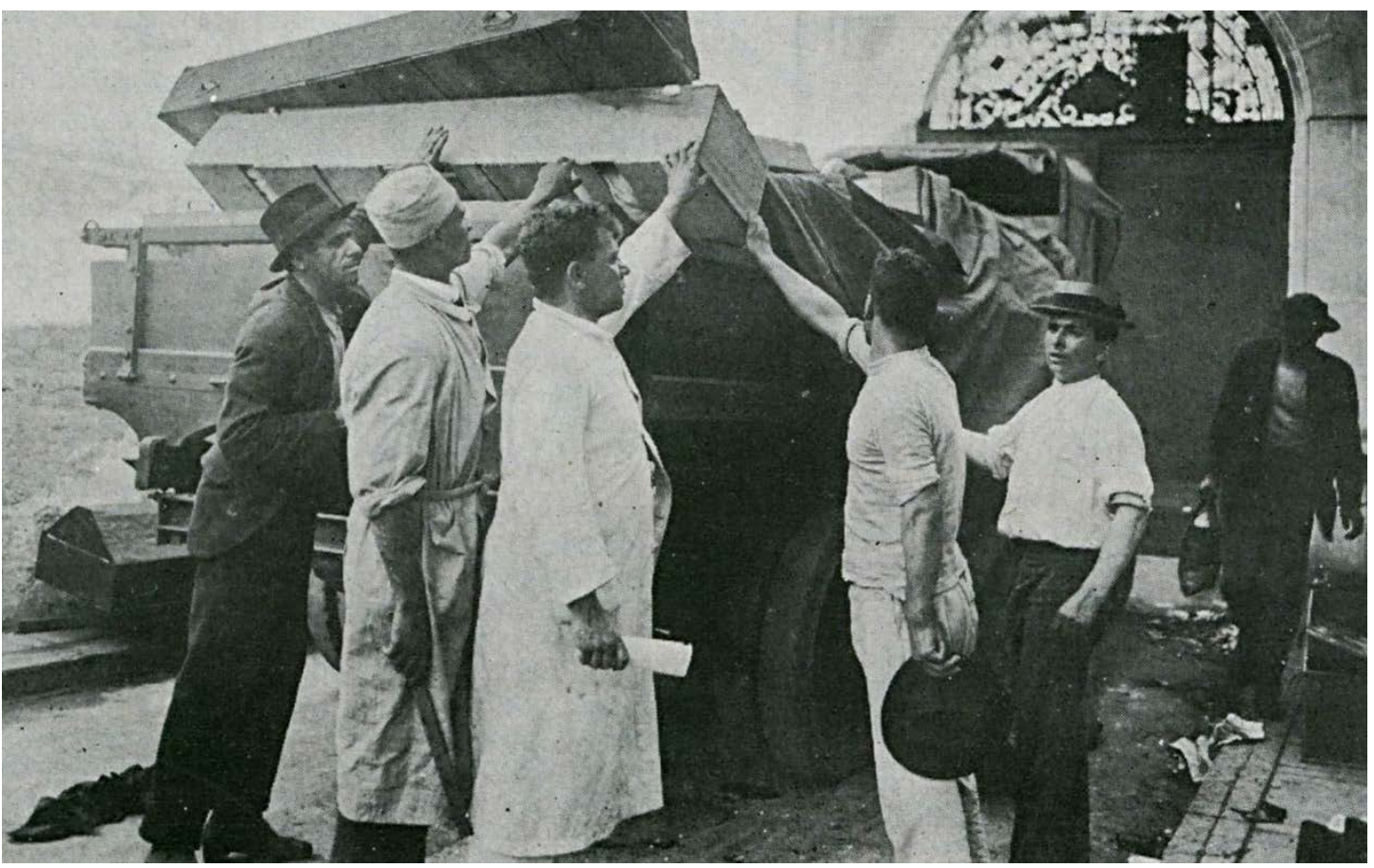

Figura 1 - Transporte de mortos, no Rio de Janeiro, durante a gripe espanhola Fonte: Careta (1918) ${ }^{9}$.

Mas a busca precisava continuar. Havia que ir na direção da última lembrança: a dos corpos sendo sepultados em valas abertas nas ruas dos bairros mais longínquos. Olhando detidamente as revistas, muitas fotografias passaram diante de meus olhos: enfermarias lotadas, populares aglomerados em busca de alimentos para matar a fome, naquilo que com frequência era denominado 'socorros à pobreza', e as muitas 'procissões de preces' que as paróquias de diversas irmandades católicas realizavam. Havia também pilhas de caixões insepultos, à espera dos coveiros, porém todos nos cemitérios da cidade.

As inúmeras descrições dos "episódios do tempo da peste" (p. 8) também apontam ora para o macabro espetáculo dos caminhões conduzindo cadáveres descobertos, ora para a visão dos cemitérios do Rio, "onde se empilham os caixões funerários aguardando sepultura" ${ }^{\prime 10}$ (p. 18). "São oito e meia horas da manhã de uma quarta feira cheia de sol. A esquina da rua Pedro Américo e Catete, na delegacia, a uma quadra do Palácio do Governo, para um caminhão conduzindo cadáveres descobertos, sem caixão, estendidos nas taboas. O caminhão ai estaciona, durante uma hora, diante da quitanda, do açougue, da venda da padaria. Quando esse parte, chega o segundo, expondo o corpo morto de uma pobre mulher, cuja saia rota na alvura do ventre, põe uma nota de crueldade indecorosa nessa miséria fúnebre. $\mathrm{O}$ terceiro caminhão chega às dez, e enquanto o condutor vai beber um parati no botequim fronteiro, as crianças trepam pelas rodas, para espiar os defuntos. O quarto caminhão, contendo numerosos cadáveres, aparece as onze e desaparece ao meio dia e por onde roda espalha um cheiro desagradável e entontecedor. Na rua do Catete, na rua Barão de Guaratiba, na rua Pedro Américo, uma assustada multidão, desentocando-se das casas fechadas, vêm contemplar a passagem desses trágicos carros. Os passageiros dos bondes levam ao nariz os lenços" ${ }^{\prime \prime}$ (p. 8).

As revistas continuavam a ser folheadas. Os caixões insepultos agora faziam a imaginação saltar tempos e mergulhar ainda mais na busca da última imagem primordial. E eles apareciam seguidamente. Ora era o emaranhado de caixões, uns sobre os outros, no Cemitério do Caju, ora destacavam outras pilhas de corpos envoltos apenas em lençóis sendo transportados em cemitérios dos subúrbios, como em Inhaúma, tendo ao lado e à espera esquifes abertos. 
Na imagem reproduzida a seguir (Figura 2), pilhas de caixões insepultos, esperando o gesto da abertura das valas coletivas, transportam minha memória para o presente, quando, agora em cores, presenciei nos noticiários da televisão imagens semelhantes multiplicando-se pelas cidades brasileiras.

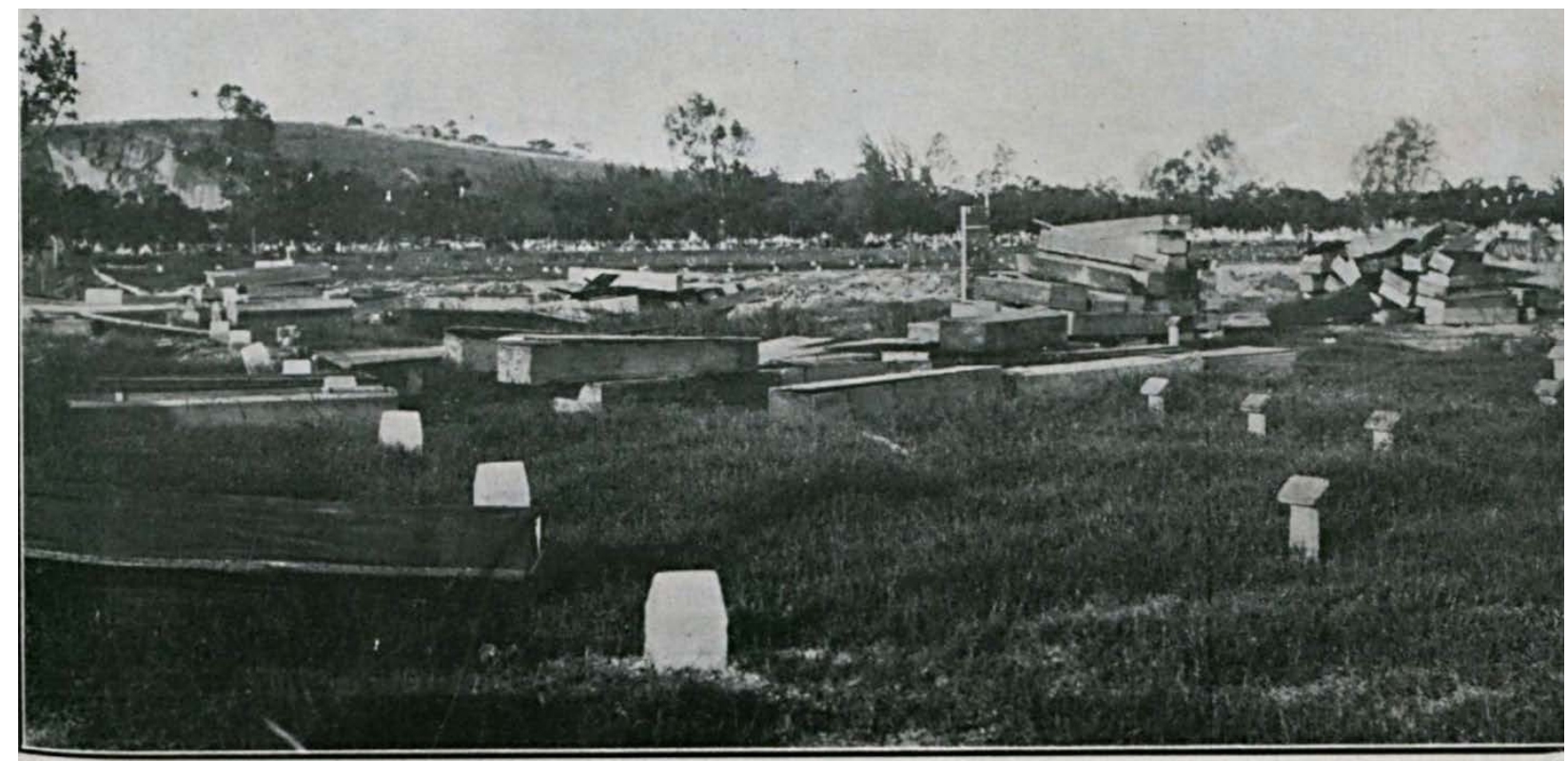

Caixões mortuarios no Cajü, insepultos por falta de coveircs

Figura 2 - Caixões espalhados no Cemitério do Caju, Rio de Janeiro Fonte: Careta $(1918)^{11}$.

A fotografia seguinte (Figura 3), também publicada pela revista Careta, mostra, informa a legenda, o transporte de cadáveres no Cemitério de Inhaúma. Na foto, apenas duas personagens estão presentes no quadro. Ao lado delas, um caixão aberto espera o corpo inerte envolto em panos. Ao longe, vemos o que parece ser um campanário e a solidão do descampado que contagia o primeiro plano da fotografia. Sem nenhuma testemunha, sem nenhum acompanhante, sem ninguém, o corpo será colocado no caixão.

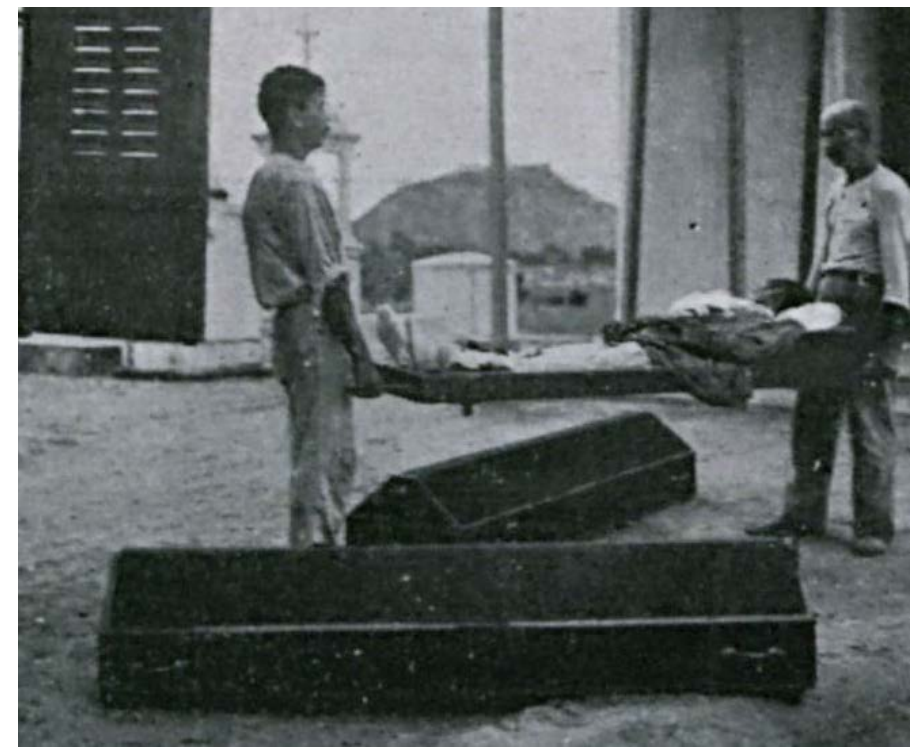

Figura 3 - Transporte de mortos em Inhaúma Fonte: Careta $(1918)^{12}$ 
Todas essas imagens guardam alguma relação com a cena que eu continuava procurando, mas não encontrei. A segunda imagem-memória de meu pai não ficou imortalizada nas publicações da época, apesar destas produzirem edições para o futuro, procurando um lugar na história' ${ }^{13}$. Não havia as fotos das valas das ruas do subúrbio recebendo os mortos.

\section{FLUXOS ENCADEADOS DA MEMÓRIA}

O que estamos denominando, portanto, fluxos encadeados da memória são essas tramas duradouras, em que as lembranças originais, por terem começado numa narrativa primordial, permanecem durando nas lembranças do outro, produzindo uma conexão do acontecimento original não como fato, mas como possibilidade memorável.

Há sempre um fluxo, nos trabalhos de memória, que relaciona as lembranças individuais a de outros (familiares, grupos, pessoas etc.), conforme remarcam diversos teóricos sobre a complexa questão memorável ${ }^{4,14-19}$. O que nos interessa aqui, no entanto, é mostrar como esse encadeamento se transborda para além dos mecanismos de transmissão memorável de pessoa para pessoa, tomando a cena pública por meio de outras ações comunicacionais.

Se o fluxo da memória se deu, num primeiro momento, de meu pai em minha direção, ao acionar o elemento desencadeador das lembranças, no futuro fiz, uma vez mais, das tramas comunicacionais possibilidades de materialização daquelas lembranças. Ao falar das cenas de 1918 para mim, naquele hoje longínquo ano de 1960, o ato comunicacional narrativo foi o que fixou as imagens-lembranças da gripe espanhola de 1918. Quase 60 anos depois, a ação que a memória desencadeou foi novamente um gesto comunicacional: fui buscar as imagens das narrativas originais que talvez tivessem perdurado no tempo.

Ao encontrar essas imagens, estaria atestando a marca veritativa da memória de meu pai e da minha própria memória, num novo encadeamento como fluxo memorável, agora mediante a materialidade documental das imagens fotográficas presentes nos periódicos de outrora.

A memória, transformada em lembranças duradouras, pode sobreviver na memória do outro, que, diante, por exemplo, de um acontecimento impactante, traumático e sobre o qual constrói similitudes, vai buscar nas profundezas adormecidas palavras escutadas em outras épocas. Nesse momento, ecoa o som das vozes ouvidas no passado e imagens emergem. Há uma espécie de despertar na memória daquilo que estava adormecido, induzindo à ação.

A ação deu-se, nesse caso, pela busca de imagens que pudessem referendar lembranças até então adormecidas. Observa-se que a memória do outro, que originalmente presenciara aquelas cenas, continuava ecoando na memória daquele que um dia qualquer escutou narrativas, histórias como fluxos, produzindo outros fluxos encadeados de memória.

Assim, o texto descreve cenas longínquas fixadas em lembranças duradouras e que levam à ação: a busca das imagens e das coberturas jornalísticas publicadas durante a gripe espanhola, na cidade do Rio de Janeiro, entre setembro e novembro de 1918. Num segundo movimento, analisa um conjunto restrito de fotografias publicadas na revista Careta, imagens que sintetizam as cenas descritas originalmente e que, assim, possuem reflexividade em relação às lembranças duradouras. Dessa forma, apenas as imagens veritativas da memória original ou aquelas que guardam vínculos com a descrição primeira foram reinscritas neste artigo.

O objetivo não é mostrar imagens impactantes da gripe espanhola, nem as analisar, mas tão somente estabelecer elos com esses fluxos memoráveis, dos quais agora as imagens publicadas nas revistas da época fazem parte. Ao materializar a lembrança, o periódico torna-se, também ele, elo do fluxo memorável, uma vez que permite realizar uma nova inscrição do acontecimento nas tramas do contemporâneo. 
Na cobertura jornalística construída por alguns dos principais jornais diários do Rio de Janeiro na época, no desenrolar do acontecimento, inicialmente se registravam aqui e ali, de maneira esparsa, as notícias sobre a 'influenza', em páginas secundárias. No momento seguinte, tais notícias ganharam a primeira página, sendo até mesmo capazes de desbancar o fim da Primeira Guerra Mundial nesses espaços nobres dos jornais. No fluxo narrativo, dia após dia, gradativamente se construiu também o esquecimento, retirando num primeiro momento as notícias da gripe de suas primeiras páginas, fazendo-as ocupar, de novo, espaço secundário, até desaparecer totalmente do noticiário. A construção do acontecimento, que fez transbordar suas primeiras páginas com manchetes e textos que as ocupavam inteiramente, caminhava em direção ao esquecimento profundo, de tal forma que nos permite afirmar que o mesmo jornalismo que fixa para o futuro o acontecimento, transformado em documento, produz, no momento de sua construção, o esquecimento como trama mais duradoura de suas narrativas. Há, portanto, uma apropriação temporal das narrativas jornalísticas que também as situa num particular fluxo memorável.

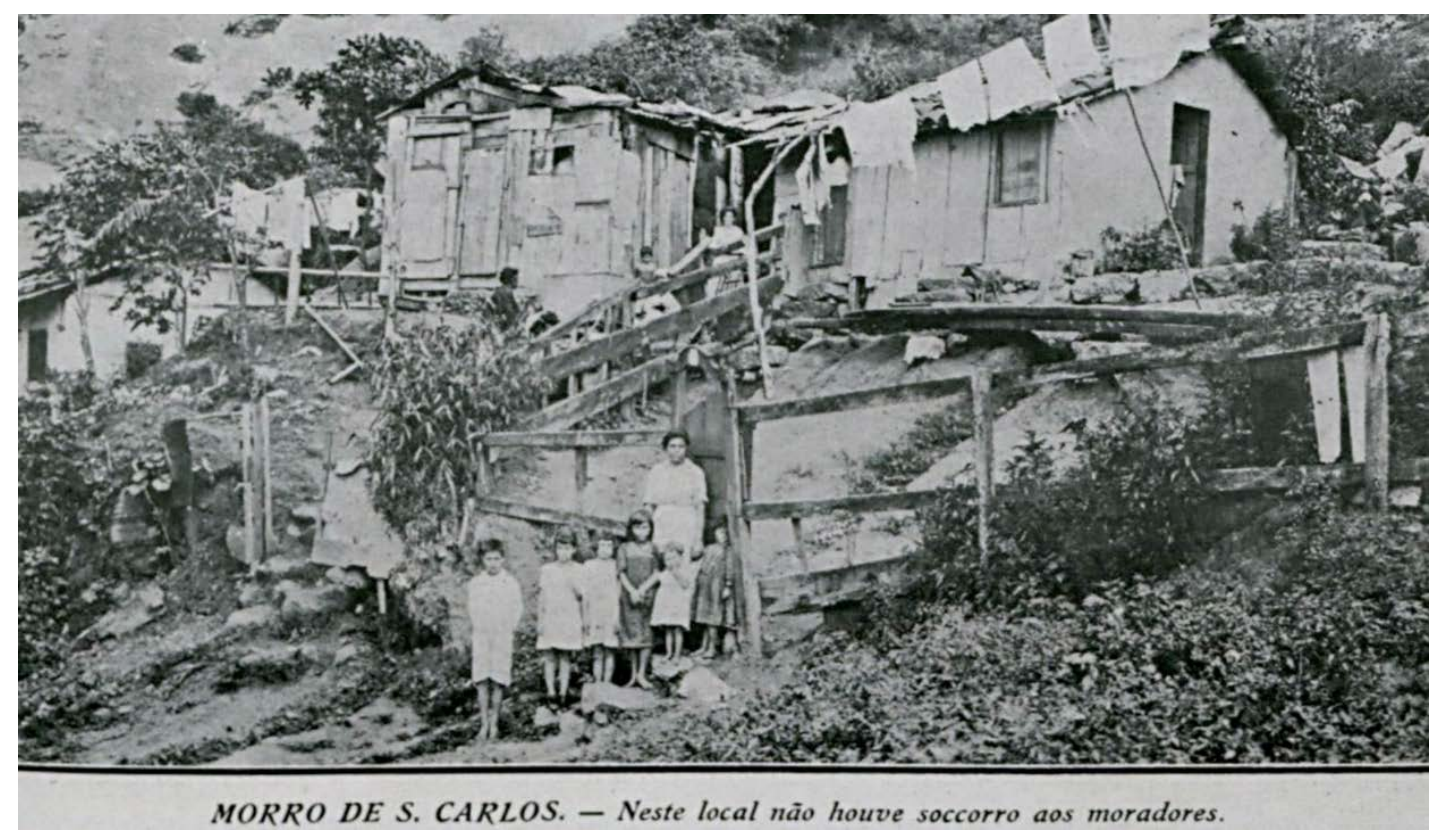

Figura 4 - Cena do Morro de São Carlos

Fonte: Careta $(1918)^{20}$.

\section{CONSIDERAÇÕES FINAIS}

A imagem da revista Careta com que terminamos a seção anterior (Figura 4), mostrando uma cena de moradores do Morro de São Carlos, acompanhada da informação de que naquele local não houve socorro aos moradores, revela que os fluxos narrativos e de ação não são exclusivos da questão memorável ${ }^{21}$.

No passado, assim como no presente, as vidas pobres pouco importam. As condições insalubres de moradia, a alimentação deficiente nesses morros e nos casebres dos subúrbios significaram a perda de muitas vidas nesses lugares, mas isso importou muito pouco. Se tivesse importado alguma coisa, não estaríamos vendo a repetição dessa mesma cena. Como seguir as recomendações de distanciamento, de higiene, de alimentação, capazes de fortalecer o corpo em lugares inóspitos e para os quais não dirigimos nenhum olhar, nenhum gesto?

Ao construir o artigo com base em uma experiência pessoal, convidando o leitor a ingressar em tempos pretéritos, a partilhar experiências vividas por gerações em localidades e subúrbios longínquos da cidade do Rio de Janeiro, que deixavam à mostra as mazelas cotidiana de milhares de pessoas sem assistência e 
entregues à própria sorte, fiz das tramas memoráveis uma espécie de pretexto para indicar a sobrevivência de múltiplas permanências.

Se a primeira delas foi construída com base em uma reflexão teórica, permitindo navegar no conceito de fluxos encadeados da memória, apontando as teias de relações múltiplas que os constituem por intermédio dos atos comunicacionais, muitas outras se apresentam nas imagens sobreviventes e indicam que a passagem do tempo não apaga as marcas duradouras das mazelas de desigualdade social no país.

Mais de 20 mil mortos, estampava a notícia da Gazeta de Notícias7, ao fazer o balanço das vítimas da gripe espanhola em novembro de 1918 na cidade do Rio de Janeiro. Se, no início, havia a divulgação generalizada de que a epidemia ceifava a vida de ricos e pobres, o desenrolar da trama mostrou que matou, sobretudo, pobres. Eram eles que viviam nos casebres insalubres, que não tinham alimentação que pudesse minimamente produzir defesas naturais nos seus organismos. Sem comida, sem saneamento básico, vivendo aglomerados, corriam desesperados em busca das esmolas. Chamam a atenção nas fotografias que imortalizaram suas faces, nas publicações, as dezenas de crianças que aparecem nessas aglomerações humanas em busca de alimentos ou nas portas dos casebres dos morros, como na fotografia mostrada anteriormente.

Passaram-se exatos cem anos de um tempo em relação ao outro. Se, por um lado, um século não impediu a reconstrução de fluxos memoráveis, no exercício que fizemos no artigo, o mesmo tempo não foi suficiente para que a primeira pandemia do século XXI deixasse de expor a quem quiser ver que a doença ceifa principalmente a vida de milhares de pobres. Mas, tal como aconteceu em 1918, para muitos, a vida dos pobres continua não importando.

\section{REFERÊNCIAS}

1. Ellis C. The ethnographic I: a methodological novel about autoethnography. Walnut Creek: AltaMira Press; 2004.

2. Jones SH. Autoethnography: making the personal political. In: Denzin NK, Lincoln YS, editors. Handbook of qualitative research. Thousand Oaks: Sage Publications; 2005. p. 763-92.

3. Pensoneau-Conway S, Adams TE, Bolen DM. Doing autoethnography. Roterdão: Sense; 2017.

4. Halbwachs M. A memória coletiva. São Paulo: Vértice; 1990.

5. $\quad$ Barbosa M. História cultural da imprensa (1900-2000). Rio de Janeiro: Mauad X; 2007.

6. Cenas que enlouquecem. Gazeta de Notícias. 23 out. 1918:1.

7. Revista da Semana. 1918;38:18-19.

8. Careta. 26 out. $1918 ; 540: 8$.

9. Careta. 26 out. 1918;540:21.

10. Careta. 26 out. 1918;540:18.

11. Episódios do tempo da peste. Careta. 2 nov. 1918;541:8.

12. Careta. 9 nov. 1918;542:21.

13. Careta. 2 nov. 1918;541:17.

14. Barbosa M. Meios de comunicação: lugar de memória ou na história? Contracampo [Internet]. 2016 [citado em 2020 abr. 04];35(1):7-26. Disponível em: https://periodicos.uff.br/contracampo/article/ view/17558/pdf.

15. Pollack M. Memória, esquecimento, silêncio. Re Est Hist [Internet]. 1989 [citado em 2020 abr. 30 abril];2(3):3-15. Disponível em: http://bibliotecadigital.fgv.br/ojs/index.php/reh/article/view/2278/1417.

16. Candau J. Mémoire et identité. Paris: Presses Universitaires de France; 1998. 
Reciis - Rev Eletron Comun Inf Inov Saúde. 2020 out.-dez.;14(4):820-31 | [www.reciis.icict.fiocruz.br] e-ISSN 1981-6278

17. Namer G. Mémoire et société. Paris: Meridiens Klincksleck; 1987.

18. Todorov T. Les abus de la mémoire. Paris: Arléa; 1995.

19. Ricoeur P. A memória, a história e o esquecimento. Campinas: Editora da Unicamp; 2008.

20. Careta. 23 nov. 1918;544:21.

21. Ledoux S. Le devoir de mémoire. Paris: CNRS; 2016. 